Available online at http://iddtonline.info

RESEARCHARTICLE

\title{
ANALYSIS OF NUTRIENTS, TOTAL PHENOLS AND ANTIOXIDANT ACTIVITY OF FICUS SANSIBARICA WARB. FRUITS FROM EASTERN BOTSWANA
}

\author{
${ }^{*}$ Motlhanka Daniel ${ }^{1}$, Ebineng Topo ${ }^{1}$ \\ ${ }^{1}$ Botswana College of Agriculture, Medicinal Plants Research Laboratories, Department of Basic Sciences, Private Bag 0027, Gaborone, \\ Botswana \\ "Corresponding Author's E-mail: motlhankadan@yahoo.com; dmotlhan@bca.bw,Tel: 26771546727
}

Received 02 Oct 2012; Review Completed 12 Oct 2012; Accepted 01 Nov 2012, Available online 15 Nov 2012

\begin{abstract}
Ripe fruits of Ficussansabarica were assessed for in vitro antioxidant activity using the Free radical scavenging assay (FRSA). The scavenging activity of the fruits was evaluated spectrophotometrically as maximum fading power of 1,1 Diphenyl-2-picrylhydrazyl (DPPH) at $525 \mathrm{~nm}$. The total phenolic content of water and methanol extracts was determined using the Folin-Ciocalteau method. The mineral composition of the fruits was analyzed using the optical emission spectrophotometer. At all tested concentrations the scavenging power of methanolic extract was higher than that of water extract. Between 100 and $200 \mu \mathrm{g} / \mathrm{ml}$, both extracts exhibited scavenging power of $\geq 85 \%$ comparable to the standard compound quercetin. The total phenolic contents of water and methanolic extracts were 3145 and $3584 \mathrm{mg} / \mathrm{L} \mathrm{GAE}$, respectively. The fruits contained $7.83 \mathrm{mg} / \mathrm{LCa}, 9.47 \mathrm{mg} / \mathrm{LMg}, 2.66 \mathrm{mg} / \mathrm{L} \mathrm{Na}, 58.1 \mathrm{mg} / \mathrm{L} \mathrm{K}$, and $0.02 \mathrm{mg} / \mathrm{L} \mathrm{P}$. Crude protein content as determined by the Kjeldahl method was $0.18 \%$. These results show that these fruits are a rich source of the essential elements that have a positive effect on human health. The results support the use of these fruits as supplements for nutrient deficiencies and for combating diseases associated with oxidative damage.

Keywords: mineral content; Ficus sansabarica; total phenols; free radical scavenging; wild fruits.
\end{abstract}

\section{INTRODUCTION}

The use of wild foods, of which wild fruits form a part as component of local responses to increasing food insecurity is widely documented ${ }^{1,2,3,4}$. In many tropical countries, rural people traditionally harvest a wide range of roots, tubers and edible fruits from the wild because of their taste, cultural uses, as food supplements and or to alleviate food shortage ${ }^{5}$. Native edible wild fruits can play a crucial role in combating food insecurity, especially the so-called hidden hunger caused by micronutrient vitamin and mineral deficiencies ${ }^{4}$. The macro and microelemental composition of well-known tropical fruits such as banana, African pear, orange and others have been reported $^{6,7,8,9}$. In Botswana, many wild fruits notably; fruits of Sclerocarya birrea, Ziziphus mucronata, Vanguera infausta, Mimosopus zeyheri, Adenosonia digitata, Grewia $s p p^{4,10}$ are harvested from the wild to support nutritional needs of the rural communities. Other studies on nutritional analysis of some wild fruits growing in rural countryside of many developing nations, have reported better nutritional values than commercial cultivated fruits such as oranges and bananas ${ }^{8,10,11}$. As aresult, in recent years, a growing interest has emerged to evaluate various wild edible plants for their nutritional value $^{12,13,14,15,16}$. Besides nutrition, fruits are also valuable sources of bio-actives such as flavonoids, phenolic acids and free radical scavengers ${ }^{17,18}$. Many published epidemiological studies ${ }^{19,20,21}$ suggest that regular or moderate intake of food rich in polyphenols is known to have several health promoting properties such as lowering the risk of several oxidative stresses including cardiovascular diseases, cancer, stroke and ageing ${ }^{22}$. Plants produce a variety of antioxidative compounds to counteract reactive oxygen species (ROS) in order to survive $^{23}$. ROS include free radicals such as superoxide anion radical $\left(\mathrm{O}_{2}^{-}\right)$, hydroxyl radicals $(\mathrm{OH})$, and non-free radical species such as $\left(\mathrm{H}_{2} \mathrm{O}_{2}\right)$ and singlet oxygen $\left({ }^{1} \mathrm{O}_{2}\right)$. These various forms of activated oxygen are exacerbating factors in the development of cellular injury and many pathogenic states such as cancer, inflammation, heart disease and diabetes ${ }^{24}$.

In the present study, nutrient composition, total phenolic content, and antioxidant properties of F.sansibarica from eastern Botswana, were evaluated in order to validate its potential in improving health and food security for the rural communities.

\section{Ethnobotanicaldata \&species information}

Species name: Ficus sansibarica Warb.

Family name: Moraceae

Common names: Mosapu (Tswana). English: Zanzibar Fig.

Part used and mode of preparation: Ripe fruits are eaten fresh by both adults and children.

Description: Ficus sansibarica is a medium to large evergreen tree with a round spreading crown often starting life as a strangler, occurring in bushveld, usually on deep sandy soil ${ }^{25}$. The fruits are called Zanzibar fig. The knobbly fig is often about $10 \mathrm{~m}$, but sometimes becoming enormous strangler $20-40 \mathrm{~m}$ in height occurring in low altitude of $900 \mathrm{~m}$ woodland. The bark is grey, rather smooth although uneven, lumpy or folded; branches with stubby knobs where figs are borne ${ }^{26}$. The leaves are oblong to ovate, 40-170x20-105mm, hairless; apex abruptly tapering; base rounded; principal lateral veins 7-9 on either side of the mid-rid, basal pair 
conspicuous. The figs are borne in clusters (Fig.1a) on dwarf, knobbly wart-like spurs on the trunk and main branches, large up to $50 \mathrm{~mm}$ in diameter on conspicuous stalks. The figs are purplish green ripening to deep purple colour.

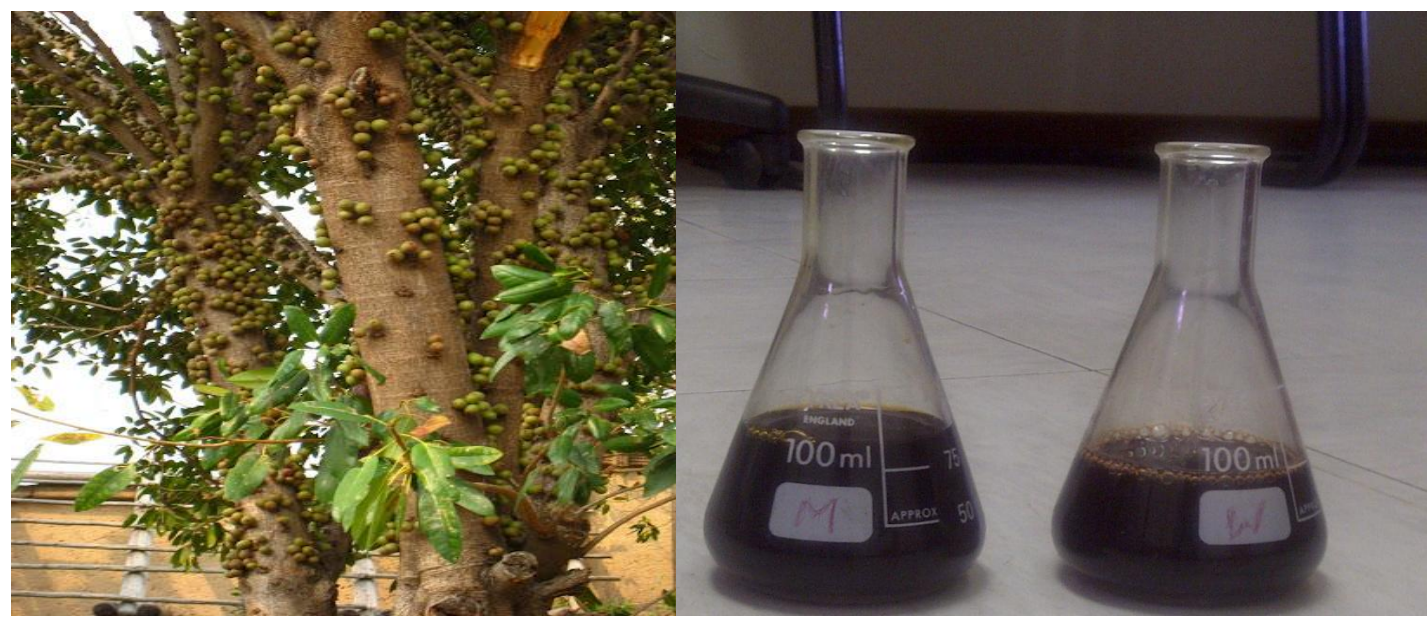

Figure 1a: Figs on branches and trunk of F.sansibarica Figure 1b: Supernatants for Methanol (M) and Water (W) extracts

\section{MATERIALS AND METHODS}

\section{Collection of the plant}

Fresh fruits of F.sansibarica were collected from the countryside of Seolwane village, (S22 $39^{\prime} 12.0^{\prime \prime}$; E027 42'13.9") Eastern Botswana. Only fully ripe purplish coloured mature fruits were detached from the plant using a sechateer. The fruits were collected in black perforated polythene bags. The samples were transported soon after their collection to the Botswana College of Agriculture Medicinal Plants Research laboratory for analysis. Genus and species of the plant were confirmed by comparison with herbarium reference materials at the Botswana National Herbarium and Gallery. Voucher specimen number (EBotMot35) has been deposited at the National Herbarium in Gaborone. Before analysis, the fruits were thoroughly washed and cleaned under a running tap. The wet fruits were then dried by means of blotting them in between soft water -adsorbent bulbous paper.

\section{Preparation of the extract}

After drying, the fruits were crushed into a pulp with the help of an electric homogenizer. The pulp was then homogenized into either $500 \mathrm{ml}$ absolute methanol or $500 \mathrm{ml}$ distilled water for four days at $4{ }^{\circ} \mathrm{C}$. The crude extracts were centrifuged thrice and filtered using Buchner funnel, till a clear supernatant (Fig.1b) was achieved. Methanol based supernatants (dark purplish) were concentrated to dryness using rotary evaporator whilst water based extracts (light purplish) were concentrated by freeze drying. The crude residues were kept at $4{ }^{\circ} \mathrm{C}$ until used.

\section{Chemicals}

1,1-Diphenyl-2-picrylhydrazyl (DPPH), Gallic acid, were purchased from Sigma Chemical Co. (St Loius, MO,USA); Folin-Ciocalteus's reagent was from Merck Chemical Supplies (Damstadt, Germany);Sodium carbonate (ACE chemicals, RSA) and Quercetin (Fluka, Switzerland).All other reagents were of analytical grade.

\section{Determination of Minerals and Crude protein}

For determination of mineral content, the homogenized crushed whole fruit pulp was dried overnight in an oven at $90^{\circ} \mathrm{C}$. The finely ground samples $(0.5 \mathrm{~g})$ were taken and digested with $20 \mathrm{ml}$ Nitric acid. After adding $10 \mathrm{ml}$ perchloric acid, the contents were heated gently on a hot plate, followed by vigorous heating till dryness (approximately 1-2ml). The minerals determined were; $\mathrm{Ca}, \mathrm{Mg}, \mathrm{Na}, \mathrm{K}$ and $\mathrm{P}(\mathrm{mg} / \mathrm{L})$. These minerals were measured using Inductively Coupled Plasma-optical Emission Spectrophotometer (ICP-OES). Nitrogen content $(\% \mathrm{~N})$ of the sample was estimated by an established reliable method ${ }^{27}$ and crude protein was calculated as $\% \mathrm{Nx} 6.25$. All the analyses were carried out in triplicates and the mean calculated.

\section{Determination of total phenolics}

Total phenol contents in the extracts were estimated using the modified Folin-Ciocalteu method ${ }^{28,29}$. An aliquot $(20 \mu \mathrm{l})$ of the extract was mixed with $100 \mu \mathrm{l}$ FolinCiocalteu reagent in a clean cuvette and mixed well. Then $300 \mu \mathrm{l}$ of $(0.2 \mathrm{~g} / \mathrm{ml})$ Sodium carbonate was added. The tubes were vortexed for $15 \mathrm{sec}$ and allowed to stand for $30 \mathrm{~min}$ at $40^{\circ} \mathrm{C}$ for colour development. Absorbance was then measured at $765 \mathrm{~nm}$ using Hewlett Packard UV-Vis spectrophotometer. Samples of extracts were evaluated at a final concentration of $0.1 \mathrm{mg} / \mathrm{ml}$. The total phenolic content was determined from the calibration curve and presented as (Gallic acid equivalent (mg/L)).

\section{DPPH radical scavenging assay}

Free radical scavenging activity of the extracts was measured in terms of the hydrogen radical scavenging ability using the stable free radical 1,1-diphenyl-2picrylhydrazyl (DPPH). Briefly a $0.1 \mathrm{mM}$ solution of DPPH in methanol was prepared and $1.0 \mathrm{ml}$ of this solution was added to $0.5 \mathrm{ml}$ of samples in different concentrations. After 20min the absorbance was measured at $525 \mathrm{~nm}$. The $\%$ scavenging power of the extracts was calculated using the following relation:

DPPH radical scavenging activity $(\%)=\left[\left(\mathrm{Abs}_{\text {blank }^{-}}\right.\right.$ $\left.\left.\left.\mathrm{Abs}_{\text {sample }}\right)\right] /\left(\mathrm{Abs}_{\text {blank }}\right)\right] \times 100$ 
whereAbs $\mathrm{Ablank}_{\text {bis }}$ is the absorbance of DPPH radical +methanol; $\mathrm{Abs}_{\text {sample }}$ is the absorbance of DPPH radical+ sample/standard.

\section{Statistical analysis}

The experimental results were expressed as (mean \pm standard deviation) of three replicates.The data was subjected to Statistical Analysis System (SAS) package. Analysis of Varience (ANOVA) was done to determine means. Test of significance was done at $5 \%$ probability level.

\section{RESULTS}

\section{Mineral content}

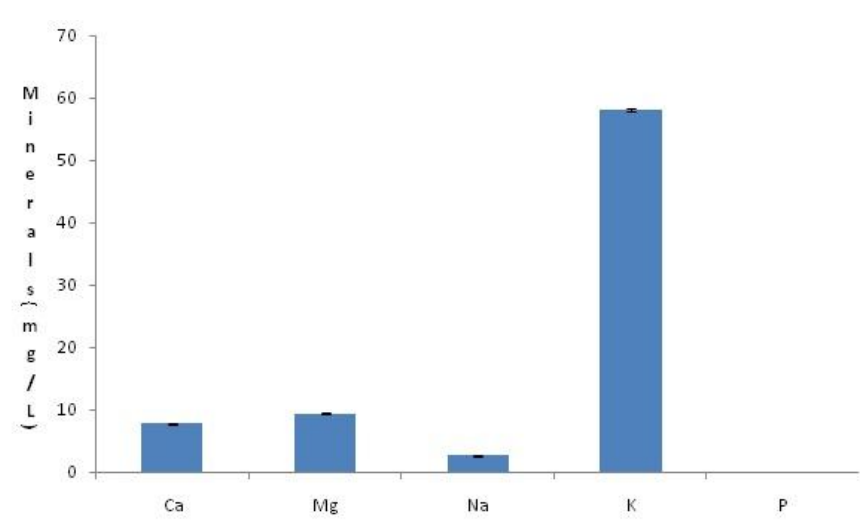

Figure 2: Mineral composition of F.sansibaricafruits (mg/L)

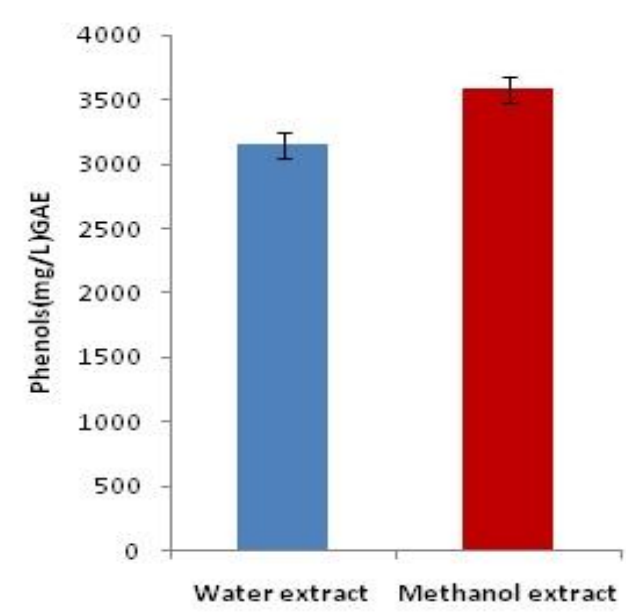

Figure 3: Total phenolic contents of water and methanol extracts of the fruits

\section{Crude protein Content $(\mathrm{CP})$}

From the $\% \mathrm{~N}$, the $\%$ crude protein was determined from the following relation:

$\% \mathrm{CP}=\% \mathrm{Nx6.25}$

The $\%$ crude protein was $0.18 \pm 0.02$.

\section{Total Phenolic Content (TPC)}

The total phenolic contents were calculated using the calibration curve for gallic acid $(\mathrm{Y}=0.001 \mathrm{x}+0.018$; $\mathrm{R}^{2}=0.990$ )

\section{Free radical Scavenging Activity}

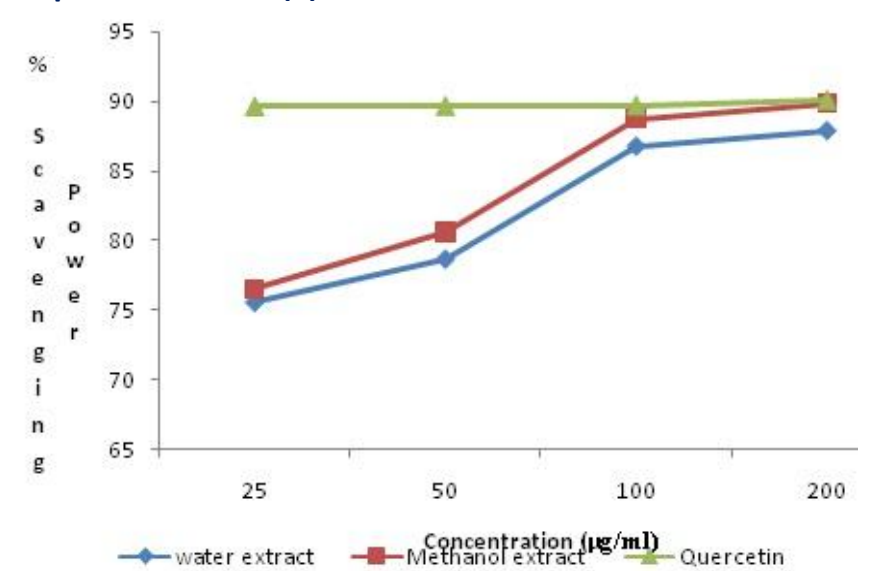

Figure 4: DPPH radical scavenging power of the fruit extracts

\section{DISCUSSIONS}

\section{Minerals and Crude protein content}

Minerals in diet are required for proper growth and good health. Potassium, Calcium, and Sodium act as electrolytes for ionic and osmotic balance, to strengthen cells and the endoskeleton ${ }^{30}$. Adenosine Triphosphate (ATP), the main source of energy in cells, must be bound to magnesium ion in order to be biologically active ${ }^{31}$. The results of the current study have revealed that, among the various macronutrients estimated from wild fruits of F.sansibarica (Fig.2) Potassium was present in the highest quantity $\left(58.1 \pm 0.26 \mathrm{mgL}^{-1}\right)$ followed by Magnesium $\left(9.47 \pm 0.02 \mathrm{mgL}^{-1}\right)$, Calcium $\left(7.83 \pm 0.08 \mathrm{mgL}^{-}\right.$ $\left.{ }^{1}\right)$, and Sodium $\left(2.66 \pm 0.09 \mathrm{mgL}^{-1}\right)$. Very low levels of Phosphorous $\left(0.02 \pm 0.01 \mathrm{mgL}^{-1}\right)$ were detected.The low level of phosphorous in plant matter (fruits) is in agreement with geological records ${ }^{32}$ that no phosphate occurrences have been reported from eastern Botswana. Similar studies on elemental analysis of wild fruits in Africa, including Botswana have revealed levels of potassium, many folds higher than the commercial cultivars like guava and banana ${ }^{5,8,10}$. Calcium and Magnesium contents too were found to be relatively high. A similar trend in levels of these elements in other wild fruits was reported ${ }^{33,34}$. The existence of sufficient quantities of essential minerals in the studied fruits suggests that the fruits may help to overcome nutrient deficiencies.

The protein content $(\%)$ of the fruits was $0.18 \pm 0.02$. This was low and is in accordance with other studies ${ }^{34}$, that the protein content of most fruits is less than $5 \%$.

\section{Total Phenolic content (TPC)}

It has been recognized that phenolic compounds are a class of antioxidant agents which act as free radical terminators ${ }^{35,36,37}$. The (TPC) was determined by FolinCiocalteu reagent in terms of the Gallic Acid Equivalent(GAE) $\mathrm{mg} / \mathrm{L}^{-1}$ using the Standard Curve equation: $\left[y=0.001 \mathrm{x}+0.018 ; \mathrm{r}^{2}=0.990\right]$. The total phenolic content(Fig.3) of water and methanolic extracts $3145.0 \pm 4.0$ and $3584.0 \pm 4.0 \mathrm{mg} / \mathrm{L}$ GAE, respectively. The observed high phenolic contents of wild fruits are in agreement with similar studies conducted on fruit pulps of Ximeniacaffra and Artobotrysbrachypetalus in Zimbabwe $^{38}$ and other wild fruits in $\mathrm{Asia}^{39}$. The TPC of methanolic extract was significantly higher than that of 
the water extract $(\mathrm{p}<0.0001)$, suggesting a higher degree of extractability by methanol than water. Alcohol such as methanol is very good for solvent extraction of polyphenols, tannins, flavones, anthocyanins ${ }^{40}$. Moreso, visual observations on the intensities of the colours of the crude extract supernatants (Fig.1b) revealed that the methanolic extract was dark purplish whilst water extract was light purplish suggesting possible higher degree of extraction by methanol than water.

\section{DPPH radical Scavenging activity}

Free radicals which are involved in the process of lipid peroxidation are considered to play a major role in numerous chronic pathologies, such as cancer and cardiovascular diseases. A compound with radical reducing power may serve as apotential antioxidant ${ }^{41}$. The DPPH radical has been widely used to evaluate the free radical scavenging ability of various natural products and has been accepted as a model compound for free radicals ${ }^{41,42}$. Radical scavenging activities of methanol and water based fruit extracts were determined using different concentrations $(25-200 \mu \mathrm{g} / \mathrm{ml})$ of each extract as shown in Figure 4. The radical scavenging activity was determined in a concentration-dependent manner and showed a linear correlation with concentration. At all tested concentrations, the scavenging power of methanolic extracts was higher than that of water extract. A similar trend was observed in their phenolic contents.

\section{REFERENCES}

1.Abbink, J. Meen ritual, Medicinal and other plants: A contribution to South-west Ethiopian Ethnobotany. Journal of Ethiopian Studies, 1993, .26(2), 1-21.

2. Getachew, A., Kelbessa, U., Dawit, D. Ethnootanical study of edible indigenous plants in some selected districts of Ethiopia. Human Ecology, 2005, 33(1), 83-118.

3. Mojeremane, W., Tshwenyane, S.O. Azanza garkeana: a valuable edible indigenous fruit tree of Botswana. Pakistan Journal of Nutrition, 2004, 3(50, 264-267.

4. Motlhanka, D.M and Makhabu, S.W. Medicinal and Edible Wild fruit plants of Botswana as Emerging New crop opportunities. Journal of Medicinal Plants Research, 2011, 5(10), 1836-1842.

5. Mahapatra, A.K., Mishra,S., Basak, C.U., Panda,C.P. Nutritional analysis of some selected Wild Edible fruits of Deciduous Forests of India: an Explorative study towards NonConventional Bio-Nutrition. Advanced Journal of Food Science and Technology, 2012, 4(1), 15-21.

6. Aremu, C.Y and Udoessien, E.I. Chemical estimation of some inorganic elements in selected tropical fruits and vegetables. Food Chemistry, 1990, 37, 229-234.

7. Burguera, J.L., Burguera, $M$ and Becerra, G.M.G. Mineral content of some fruits from Venezuela. Revista Espanola de Cincie y Tecnologia de Alimentos, 1992, 32,667-672.

8. Eromosele, I.C., Eromosele, C.O., Kuzhkuzaa, D.M. Evaluation of mineral elements and ascorbic acid contents in fruits of some wild plants. Plant Foods Human Nutrition, 1991, 41,151-154.

9. Oliva, S.R., Valdes, B. Metal concentrations in Seville Orange (Citrus aurantium) fruits from Seville (Spain) and Palermo (Italy). Annales Botanici Fennici, 2003, 40, 339-344.

10. Amarteifio, J.O and Mosase, M.O. The chemical composition of selected indigenous fruits of Botswana. Journal of Applied Science and Environmental Management, 2006, 10(2), 43-47.

11. Maikhuri, R.K., Semwal, R.L., Singh, A and Nautiyal, M.C. Wild fruits as a contribution to sustainable rural development: A
Related studies investigating relationships between phenolic contents and free radical scavenging activity ${ }^{43,44}$, 45, 46,47 have reported strong correlation between free radical scavenging and phenolic contents of wild fruits.

\section{CONCLUSION}

The data indicate that fruits of F.sansibarica are nutritionally rich. The consumption of these fruits may help overcome nutrient deficiencies that are prevalent in poor and rural areas. The higher phenolic contents with antioxidant activity further increases their potential as tools for combating diseases associated with oxidative damage. The current work is the first of its kind, providing new reference data and public awareness regarding consuming this unconventional fruit. The present study is also a step towards the standardization of these fruits as potential healthy foods.

\section{ACKNOWLEDGEMENT}

I am grateful to residents of Seolwane Village, for locating the plant, and giving information about its use. The technical staff at the National Herbarium and Gallery is highly acknowledged for the botanical identification of the plant. I would also like to acknowledge Mr Patrick Nthoiwa for assisting with statistical analysis.

\section{CONFLICT OF INTEREST}

There is no conflict of interest. case study from Garhwal Himalaya. International Journal of Sustainable Development. World Ecology, 1994, 1, 56-68

12. Aberoumand, A and Deokule, S.S. Studies on Nutritional Values of Some Wild Edible Plants from Iran and India. Pakistan Journal of Nutrition, 2009, 8(1), 26-31.

13. Glew, R.S., VanderJagt, D.J., Bosse, R., Huang, Y.S., Chuang, L.T and Glew, R.H. The Nutrient content of three edible plants of the Republic of Niger. Journal of Food Composition Analysis, 2005, 18, 15-27.

14. Musinguzi, E.L., Kikafunda, J.K and Kiremire, B.T. Promoting indigenous wild edible fruits to complement roots and tuber crops in alleviating Vitamin A deficiencies in Uganda. Proceedings of the $13^{\text {th }}$ ISTRC Symposium, 2007.p763-769.

15. Nazarudeen, A. Nutritional composition of some lesserknown fruits used by ethnic communities and local folks of Kerala. Indian Journal of traditional Knowledge, 2010, 9(2), 398-402.

16. Nkafamiya, I.I., Modibbo, U.U., Manji, A.J and Haggai, D. Nutrient content of Seeds of some wild plants. African Journal of Biotechnology, 2007, 6 (14), 1665-1669.

17. Iriti, M., Faoro, F. Grape phytochemicals: A bouquet of old and new nutraceuticals for human health. Medical Hypotheses, 2006, 67, 833-838.

18. Zhang, Y., Seeram, N.P., Lee, R., Feng, L., Heber, D. Isolation and identification of Strawberry phenolics with antioxidant and human cancer cell antiproliferative properties. Journal of Agricultural .Food Chemistry, 2008, 6, 670-675.

19. Gülcin, I., Oktay, M., Kirecci, E., Küfrevioğlu, I. Screening of antioxidant and antimicrobial activities of Anise (Pimpellaanisum L.) seeds extracts. Food Chemistry, 2003, 83, 371-382.

20. King, R.E., Bomser, J.A., Miri, D.B. Bioactivity of resveratrol. Comprehensive Reviews in Food Science and Food safety, 2006, 5, 65-70.

21. Santos-Buelga, C., and Scalbert, A. Proanthocyanidins and tannin-like compounds. Nature, occurance, diatary intake and 
Motlhanka et al

Journal of Drug Delivery \& Therapeutics; 2012, 2(6), 1-5

effects on nutrition and health. Journal of the Science of Food and Agriculture, 2000, 80, 1094-1117.

22. Willet, M.C. Balancing lifestyle and genomics research for disease prevention. Science, 2002,296 (5568), 695-698.

23. Apel, K., Hirt, H. Reactive oxygen Species: metabolism, Oxidative Stress, and Signal transduction. Annual Reviews in Plant Biology, 2004, 55, 373-399.

24. Šeruga, M., Novak, I., Jakobek, L. Determination of polyphenols content and antioxidant activity of some red wines by differential pulse voltammetry, HPLC and spectrophotometric methods. Food Chemistry, 2011, 124, 12081216.

25. Van Wyk, B and Van Wyk P. Field Guide to trees of Southern Africa.Striik Publishers, South Africa. 1997, p78.

26. Keith, Paul \& Meg Coates Palgrave. Everyone's guide to Trees of South Africa, Capetown, Struik Publishers, South Africa; 2000, p49.

27. Kjeldahl, J. Determination of protein nitrogen in food products. Encyclopedia of Food Agriculture, 1983 ,28, 757-765.

28. Blois, M.S. Antioxidant determination by use of stable free radicals. Nature, 2002, 26, 1199-1200. 29. Waterhouse, A. Folin-Ciocalteau micromethod for Total Phenol in wine. 2009.

(Http://www.waterhouse.ucdavis.edu/phenol/folinmicro.htm)31/ $\underline{08 / 2012}$

30. Ekanayake, E.R., Nair, B.M Proximate composition, mineral and aminoacid content of mature Canavalia gladiate seeds. Food Chemistry, 1998, 66, 115-119.

31. Valberg, L.S., Holt, J.M., Paulson, E., Szivek, J. Spectrochemical analysis of Sodium, Potassium, Calcium, Copper and Zinc in normal human erythrocytes. Journal of Clinical Investigation, 1965, 44, 379-389.

32. Gwosdz, W. Botswana. In: Bosse H-R, Gwosdz, W., Lorenz, W. and Wolff (eds.) Limestone and dolomite resources of Africa. Geol Jb., D. 1996, 102,78-90.

33. Holland, B., Welch, A.A., Unwin, I.D., Buss, D.H., Paul, A.A., Southgate, D.A.T McCance and Widdowson's the composition of foods. Fifth revised and extended edition.The Royal Society of Chemistry, Ministry of Agriculture, Fisheries and Food, United Kingdom. 1997. p280-302.

34. Saka, J.DK.,Msonthi, J.D. Nutritional value of edible fruits of indigenous wild trees in Malawi. Forest Ecology and Management, 1994, 64, 245-248.

35. Das, N.P., Pereira, T.A. Effects of flavonoids on thermal autooxidation of palm oil: structure-activity relationship. Journal of American Oil Chemists Society, 1990, 67, 255-258.

36. Shahidi, F., Wanasundara, P.K. Phenolic antioxidants. Critical reviews in Food Science and Nutrition, 1992 ,32, 67103.

37. Younes, M. Inhibitory action of some flavonoids on enhanced spontaneous lipid peroxidation following glutathione depletion. Planta Medica, 1981, 43, 240-245.

38. Muchuweti, M., Ndhlala, A.R., Mupure, C., Chitindingu, T., Murenje, A., Kasiyamhuru, M., Benhura, A. Phenolic content and profiles of selected wild fruits of Zimbabwe: Ximenia caffra; Artobotrys brachypetalus; Asyzygium cordatum.. International Journal of Food Science Technology, 2008, 43(8), 1333-1337.

39. Imran, M., Talpur, F.N., Jan, M.S., Khan, A., Khan, I. Analysis of nutritional components of some wild edible plants. Journal of Chemistry Society of Pakistan, 2007, 29(50), 500508 .

40. Handa, S.S., Khanuja, S.P.S., Longo, G., Rakesh, D.D. Extraction Technologies for Medicinal and Aromatic plants.International centre for science and high Technology, Trieste, 2008.p21-25.

41. Khan, T., Ahmad, M., Khan, R., Khan, H., Ejaz, A., Choudhary, M.I. Evaluation of phytochemical potentials of selected plants of Pakistan. Am lab, 2006, 38(9), 20-22

42. Arabshahi-Delouee, S., Urooj, A. Antioxidant properties of various solvent extracts of mulberry (Morusindica L) Leaves. Food Chemistry, 2007, 102(4), 1233-1240.

(c) 2011, JDDT. All Rights Reserved
43. Capecka, E., Mareczek, A., Leja, M. Antioxidant activity of fresh and dry herbs of some Lamiaceae species. Food Chemistry, 2005, 97, 654-660.

44. Fogliano, V., Verde, V., randazzo, G., Ritieni, A. A method for measuring antioxidant activity and its application to monitoring the antioxidant capacity of wines. Journal of Agricultural Food Chemistry, 1994, 47(3), 1035-1040.

45. Gao, X., Ohlander, M., Jeppsson, N., Bjork, L., Trajkovski, V. Changes in antioxidant effects and their relationship to phytonutrients in fruits of sea buckthorn (Hippophae rhamnoides L.) during maturation. Journal of Agricultural Food Chemistry, 2000, 48(5), 1485-1490.

46. Kouri, R., Tsimogiannis, D., Bardouki, H., Oreopoulou, V. Extraction and analysis of antioxidant components from Origanum dictamnuss. Innovative Food Science Emerging Technology, 2007, 8, 155-162.

47. Samarth, R.M., Panwar, M., Kumar, M., Soni, A., Kumar, M., Kumar, A. Evaluation of antioxidant and radical scavenging activities of certain radio-protective plant extracts. Food Chemistry, 2008, 106, 868-873. 